\title{
Metode Fuzzy Logíc pada Sistem Pemantauan dan Pemberian Pakan Kucing Berbasis Smartphone
}

\author{
RACHMA APRILIYANI, LISA KRISTIANA, MIRA MUSRINI BARMAWI
}

Program Studi Informatika Institut Teknologi Nasional Bandung

Email: rachmapr@itenas.ac.id

Received 20 Februari 2020| Revised 12 April 2020 | Accepted 10 Mei 2020

\begin{abstract}
ABSTRAK
Kucing merupakan hewan peliharan yang perlu diberi pakan secara rutin oleh pemiliknya karena ada sebagian kucing yang mudah terserang penyakit dikarenakan pola makan yang tidak teratur. Untuk mengatasinya, penelitian ini mengusulkan membangun sistem kecerdasan buatan untuk memberi pakan kucing secara terjadwal serta mengetahui kondisi kesehatan kucing dengan memanfaatkan Raspberry Pi, sensor berat dan sensor gerak dengan masukan dari sensor yang telah terpasang di sekitar tempat pakan kucing. Data yang didapat berupa data pakan yang dihabiskan kucing dan data gerak kucing kemudian diterapkan metode fuzzy logic Sugeno untuk menentukan kondisi kesehatan kucing. Dari hasil penelitian didapatkan nilai status sebesar 71\%, 76\% dan $80 \%$ untuk masing-masing kucing. Nilai tersebut termasuk kedalam kategori kondisi kucing sehat sehingga tindakan yang dilakukan pemilik yaitu menjaga pola makan kucing. Pada smartphone ditampilkan informasi mengenai data pakan kucing, status, dan kondisi kesehatan kucing.
\end{abstract}

Kata Kunci: kesehatan kucing, Raspberry Pi, kecerdasan buatan, fuzzy logic Sugeno, smartphone.

\begin{abstract}
Cats is one kind of pets that need to be fed regularly by their owners because some cats are susceptible to disease due to their irregular diet. This research proposes to build an artificial intelligence system to provide cat food regularly and can determine the health condition of cats, this system was built using the Raspberry Pi, weight sensor and motion sensor with input from the sensors that has been installed around the cat feed area. The data obtained in the form of feed data consumed by cats and cat motion data then Sugeno fuzzy logic method is applied to determine the health condition of the cat. From the results, each cat has a status value of $71 \%, 76 \%$ and $80 \%$. This status value is included in the category of a healthy cat condition so the action taken by owners is to maintain the cat's diet. The smartphone displays information about cat feed data, status and health conditions of cats.
\end{abstract}

Keywords: cat health, Raspberry Pi, fuzzy logic Sugeno, artificial intelligence, smartphone. 


\section{PENDAHULUAN}

Kucing membutuhkan makanan serta minuman yang perlu diberikan oleh pemiliknya secara rutin. Pemberian pakan kucing biasa dilakukan sebanyak dua kali dalam sehari. Untuk pemberian pakan biasanya disesuaikan oleh pemilik dengan jam tertentu, misalkan pada pukul 7 pagi dan pukul 4 sore. Pemberian pakan pada hewan yang tidak tepat dapat membuat hewan kelaparan sehingga dapat menyebabkan hewan akan memiliki penyimpangan substansial dalam parameter fisik dan perilaku yang berakibat hewan menjadi stres atau tertekan (Baehaki \& Lestariningati, 2017). Oleh karena itu apabila kucing sudah beranjak dewasa, kucing harus dibiasakan mempunyai pola makan yang teratur dengan kandungan nutrisi pakan yang tercukupi sehingga dapat menghasilkan kondisi tubuh yang optimal (Hartuti, dkk, 2013).

Bagi orang-orang yang mempunyai aktivitas padat tentunya akan cukup sulit untuk memelihara hewan peliharaan seperti kucing karena keterbatasan waktu yang membuat pemilik setiap saat tidak berada di rumah untuk menjaga atau memberi pakan kucingnya. Kebanyak orang lalai untuk membuat jadwal pemberian pakan kucing dalam satu hari yang mengakibatkan kucing mempunyai pola makan yang tidak disiplin dan tidak teratur sehingga kucing menjadi kelaparan dan kucing mencari makanan di luar yang tidak diketahui nilai gizinya (Komaeni, 2016). Begitu juga saat pemilik kucing meninggalkan rumahnya untuk waktu yang cukup lama sehingga harus meninggalkan kucing yang perlu diberi pakan.

Memperhatikan makan kucing dan tingkat keaktifan kucing merupakan hal yang penting apabila kucing tidak makan atau makan lebih daripada biasanya dan kucing menjadi lesu atau tidak bertenaga maka tandanya kucing tersebut sakit (Elliott, 2021). Mengenali kesehatan pada kucing sangat penting dilakukan oleh pemilik. Oleh karena itu memahami tanda-tanda kucing yang tidak sehat merupakan tindakan penting (Vadreas \& Nirad, 2018).

Dalam rangka menjawab permasalahan yang terjadi mengenai pemberian pakan kucing yang tidak terjadwal sehingga kucing memiliki pola makan yang tidak beraturan dan tidak disiplin yang dapat mempengaruhi kondisi kesehatan kucing maka diperlukan sistem yang dapat memberi pakan kucing secara tepat (sesuai kebutuhan pakan kucing) dan kucing mempunyai jadwal pakan yang teratur serta dapat mengetahui kondisi kesehatan kucing.

Tujuan dari penelitian ini untuk menerapkan metode fuzzy logic Sugeno pada sistem pemantauan dan pemberian pakan kucing secara tepat (sesuai kebutuhan pakan kucing) serta kucing mempunyai jadwal pakan yang teratur sehingga sistem dapat menentukan kondisi kesehatan kucing dilihat dari parameter pakan yang dihabiskan kucing dan aktivitas gerak kucing.

Untuk pemberian jumlah pakan kucing sebanyak 55 gram sesuai dengan kebutuhan normal pakan kucing berdasarkan survei dari dokter hewan dan pakan kucing yang digunakan hanya pakan kucing jenis pellet dan menggunakan satu jenis merek pakan yaitu Royal Canin serta pada penelitian ini menggunakan 3 kucing peliharaan dengan masing-masing umur lebih dari 1 tahun (Dewasa) berjenis Domestik yang diletakan di dalam ruangan dan ruangan tersebut hanya berisikan satu kucing. Untuk penentuan kondisi kesehatan kucing hanya dilihat berdasarkan pada jumlah pakan yang dihabiskan kucing dan jumlah aktivitas gerak kucing. 


\section{METODOLOGI PENELITIAN}

\subsection{Fuzzy Logic}

Logika fuzzy (fuzzy logic) merupakan cabang dari sistem kecerdasan buatan (Artificial Intelligent) yang mengemulasi kemampuan manusia dalam berpikir ke dalam bentuk algoritma yang kemudian dijalankan oleh mesin (Trimartanti, 2011). Pada sistem yang dibangun menggunakan fuzzy logic Sugeno untuk menentukan kondisi kesehatan kucing berdasarkan data pakan yang dihabiskan kucing dan aktivitas gerak kucing. Dengan diterapkannya logika fuzzy, masing-masing kucing dapat berbeda kondisinya sesuai variabel masukan. Berikut merupakan tahapan yang perlu dilakukan dalam implementasi metode fuzzy logic Sugeno (Mahargiyak et al., 2013):

1. Fuzzyfikasi

Fuzzyfikasi merupakan proses memetakan nilai crips (numerik) ke dalam himpunan fuzzy dan menentukan derajat keanggotaannya (Lestari, 2016). Pada Gambar 1. merupakan pemetaan himpunan fuzzy.

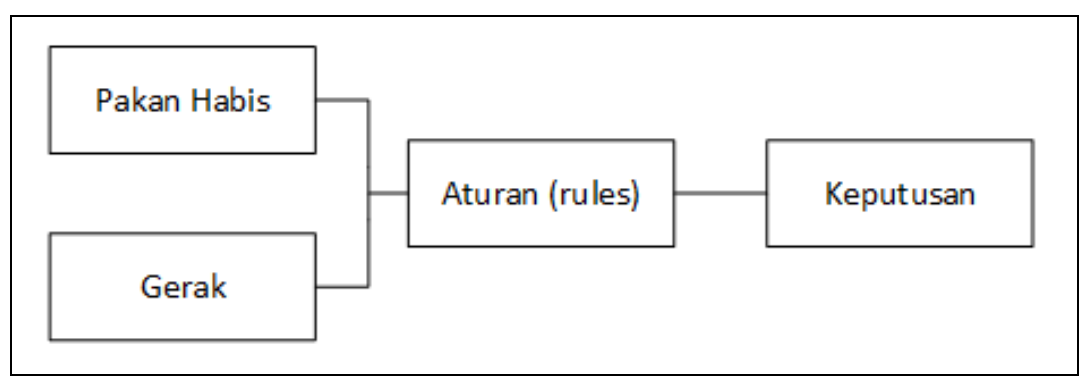

Gambar 1. Proses Fuzzy

Berdasarkan Fuzzy Inference System yang ditunjukkan pada Gambar 1. maka pemetaan himpunan fuzzy yaitu:

a) Variabel Pakan, terbagi menjadi 3 himpunan fuzzy yaitu sedikit, cukup dan banyak. Nilai dari variabel pakan berbeda-beda sesuai dengan kategori berat kucing seperti yang direpresentasikan pada Tabel 1 . Nilai tersebut didapatkan dari hasil diskusi bersama dokter hewan.

Tabel 1. Range Nilai Pakan Kucing

\begin{tabular}{|c|c|c|c|c|c|}
\hline & \multicolumn{4}{|c|}{ Kategori Berat } \\
\hline & & $3 \mathbf{~ k g}$ & $4 \mathbf{~ k g}$ & $5 \mathbf{k g}$ & $6 \mathrm{~kg}$ \\
\hline \multirow{3}{*}{ 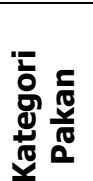 } & Sedikit & $<36 \mathrm{~g}$ & $<45 \mathrm{~g}$ & $<54 \mathrm{~g}$ & $<62 \mathrm{~g}$ \\
\hline & Cukup & $31-51 \mathrm{~g}$ & $40-60 \mathrm{~g}$ & $49-69 g$ & $57-77 \mathrm{~g}$ \\
\hline & Banyak & $>46 \mathrm{~g}$ & $>55 \mathrm{~g}$ & $>64 \mathrm{~g}$ & $>72 \mathrm{~g}$ \\
\hline
\end{tabular}

Pada Gambar 2. merupakan grafik derajat keanggotaan fungsi trapesium yang akan digunakan pada proses fuzzyfikasi (Princy \& Dhenakaran, 2016). 


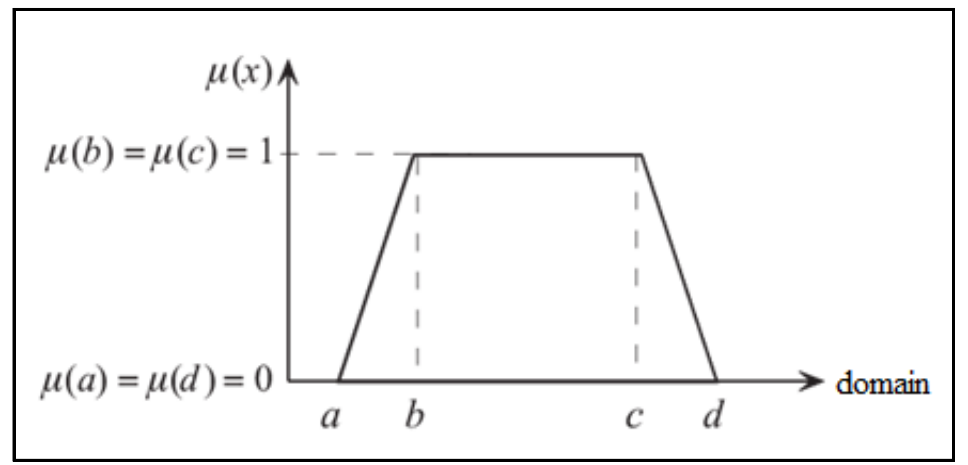

Gambar 2. Grafik Derajat Keanggotaan Fungsi Trapesium

Perhitungan fungsi keanggotaan trapesium ditunjukkan pada Persamaan 1.

$$
\mu A(x)=\left\{\begin{array}{ccc}
0 & ; \quad x \leq a \\
\frac{x-a}{b-a} ; & a<x<b \\
1 & ; b \leq x \leq c \\
\frac{d-x}{d-c} ; & c<x<d \\
0 ; & x \geq d
\end{array}\right.
$$

b) Variabel gerak, terbagi menjadi 2 himpunan fuzzy yaitu pasif dan aktif. Pada Tabel 2. merupakan range nilai untuk variabel gerak. Nilai tersebut didapatkan dari hasil diskusi bersama dokter hewan.

\section{Tabel 2. Range Nilai Gerak Kucing}

\begin{tabular}{|c|c|}
\hline $\begin{array}{c}\text { Kategori } \\
\text { Gerak }\end{array}$ & $\begin{array}{c}\text { Range } \\
\text { (Tempat) }\end{array}$ \\
\hline Pasif & $0-3$ \\
\hline Aktif & $2-4$ \\
\hline
\end{tabular}

c) Variabel keputusan yaitu mengenai status kucing yang terbagi menjadi tiga himpunan fuzzy yaitu tidak normal, cukup normal dan normal. Pada Tabel 3. merupakan range nilai untuk variabel keputusan. Nilai tersebut didapatkan dari hasil diskusi bersama dokter hewan.

Tabel 3. Range Nilai Status Kucing

\begin{tabular}{|l|c|}
\hline Status Kucing & Nilai (\%) \\
\hline Tidak Normal & $0-30$ \\
\hline Cukup Normal & $30-50$ \\
\hline Normal & $50-100$ \\
\hline
\end{tabular}

2. Mesin Inferensi Fuzzy

Pada bagian ini dibahas mengenai kaidah fuzzy (rules) atau aturan yang akan diterapkan untuk penentuan kondisi kesehatan kucing berdasarkan pakan yang dihabiskan kucing dan aktivitas gerak kucing yang didapatkan dari hasil diskusi bersama dokter hewan yang dijelaskan pada Tabel 4. 
Tabel 4. Rules Fuzzy

\begin{tabular}{|c|c|c|c|}
\hline \multirow{2}{*}{$\begin{array}{c}\text { Rule } \\
\text { Ke- }\end{array}$} & \multicolumn{2}{|c|}{ IF } & Then \\
\cline { 2 - 4 } & Makan & Gerak & Status \\
\hline 1 & Sedikit & Pasif & Tidak Normal \\
\hline 2 & Sedikit & Aktif & Cukup Normal \\
\hline 3 & Cukup & Pasif & Normal \\
\hline 4 & Cukup & Aktif & Normal \\
\hline 5 & Banyak & Pasif & Cukup Normal \\
\hline 6 & Banyak & Aktif & Normal \\
\hline
\end{tabular}

Setelah dibuat aturan-aturan fuzzy kemudian digunakan fungsi implikasi min yaitu dengan mencari nilai minimum pada setiap aturan fuzzy.

3. Defuzzyfikasi

Defuzzifikasi adalah langkah terakhir dalam proses fuzzy logic dengan tujuan untuk mengonversi hasil dari setiap inference engine yang diekspresikan kedalam bentuk fuzzy set ke suatu bilangan real. Defuzzifikasi pada metode fuzzy logic Sugeno menggunakan rumus rata-rata (average) seperti yang ditunjukkan pada Persamaan 2.

$$
W A=\frac{\alpha_{1} z_{1}+\alpha_{2} z_{2}+\alpha_{3} z_{3}+\cdots+\alpha_{n} z_{n}}{\alpha_{1}+\alpha_{2}+\alpha_{3}+\cdots+\alpha_{n}}
$$

Keterangan:

$W A=$ nilai rata-rata,

$\alpha_{n}=$ nilai predikat aturan ke-n,

$Z_{n} \quad=$ indeks nilai output (konstanta) ke-n.

\subsection{Rancangan Umum}

Pada Gambar 3. merupakan blok diagram dari sistem pemantauan dan pemberian pakan kucing secara tepat (sesuai kebutuhan pakan kucing) berbasis smartphone dengan menerapkan metode fuzzy logic.

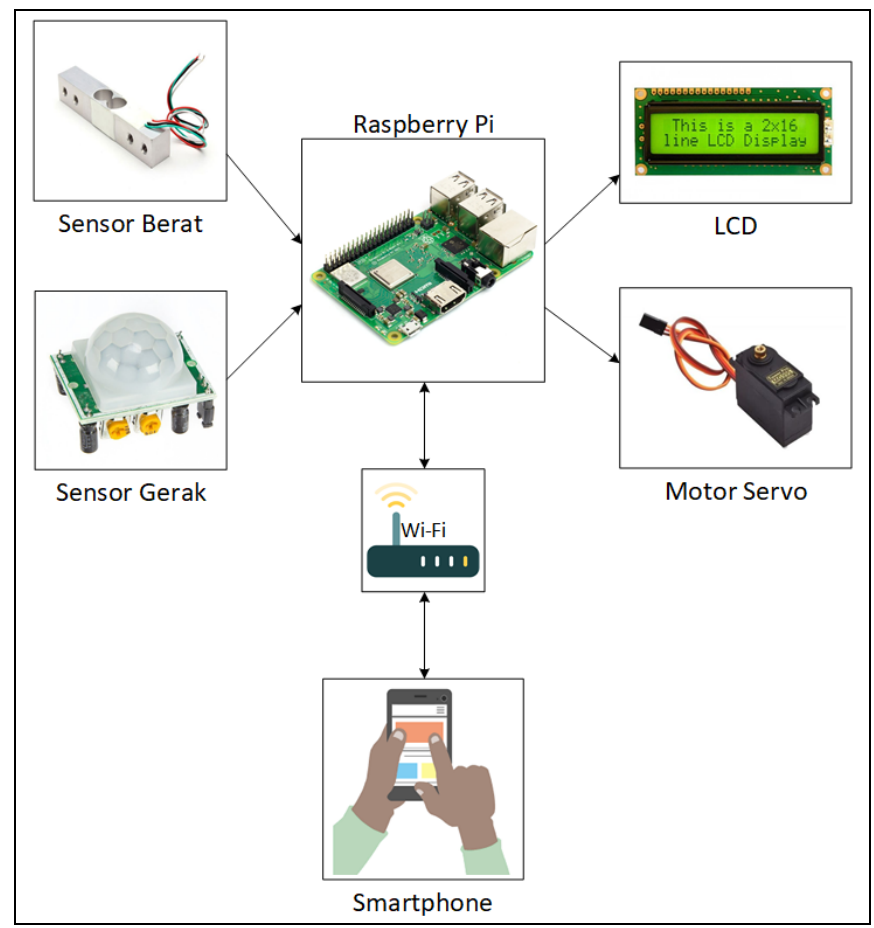

Gambar 3. Blok Diagram Sistem 
Dapat dijelaskan bahwa sensor gerak (PIR), sensor berat (Load cell) dan smartphone merupakan masukan (input) pada sistem dan dijadikan sebagai acuan agar Raspberry Pi dapat mengolah (process) data yang didapatkan dari sensor berat berupa data berat kucing dan pakan kucing, sensor gerak untuk mendapatkan data mengenai aktivitas gerak pada kucing dan smartphone yang telah terkoneksi dengan jaringan Wi-Fi untuk memasukkan jadwal pemberian pakan kucing. Sedangkan keluaran (output) pada LCD untuk menampilkan data mengenai berat kucing dan ketersediaan pakan kucing pada wadah, motor servo untuk pergerakan keluarnya pakan dari penampungan ke wadah tempat pakan kucing dan smartphone yang telah terkoneksi dengan jaringan Wi-Fi untuk menampilkan data mengenai kondisi kucing. Pada Gambar 4. merupakan rancangan fisik alat dari rangkaian sistem yang dibuat.

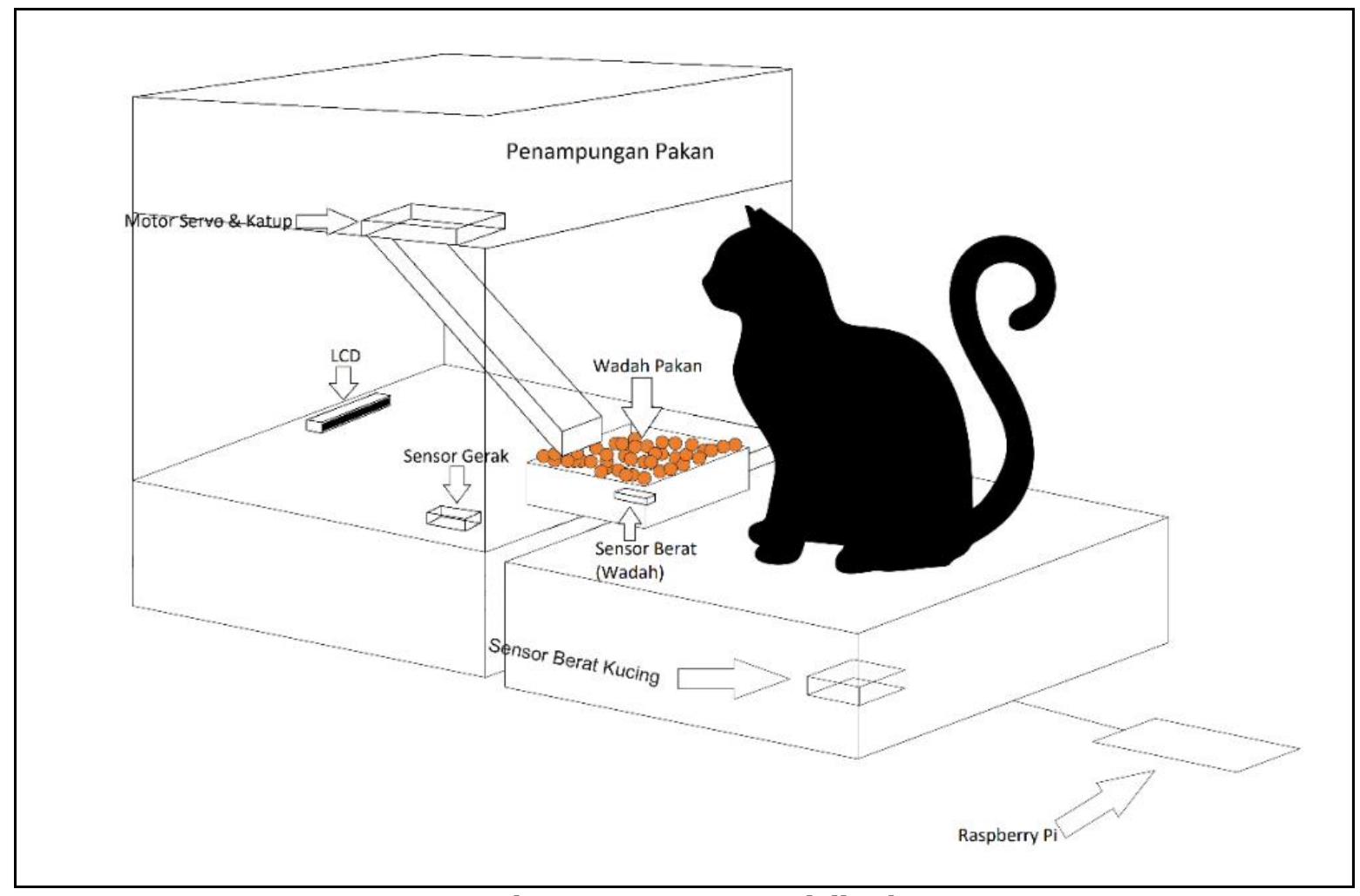

Gambar 4. Rancangan Fisik Alat

\subsection{Workflow}

Pada Gambar 5. merupakan workflow dari sistem pemantauan dan pemberian pakan kucing secara tepat (sesuai kebutuhan pakan kucing) berbasis smartphone dengan menerapkan metode fuzzy logic, penjelasan untuk setiap prosesnya sebagai berikut. 


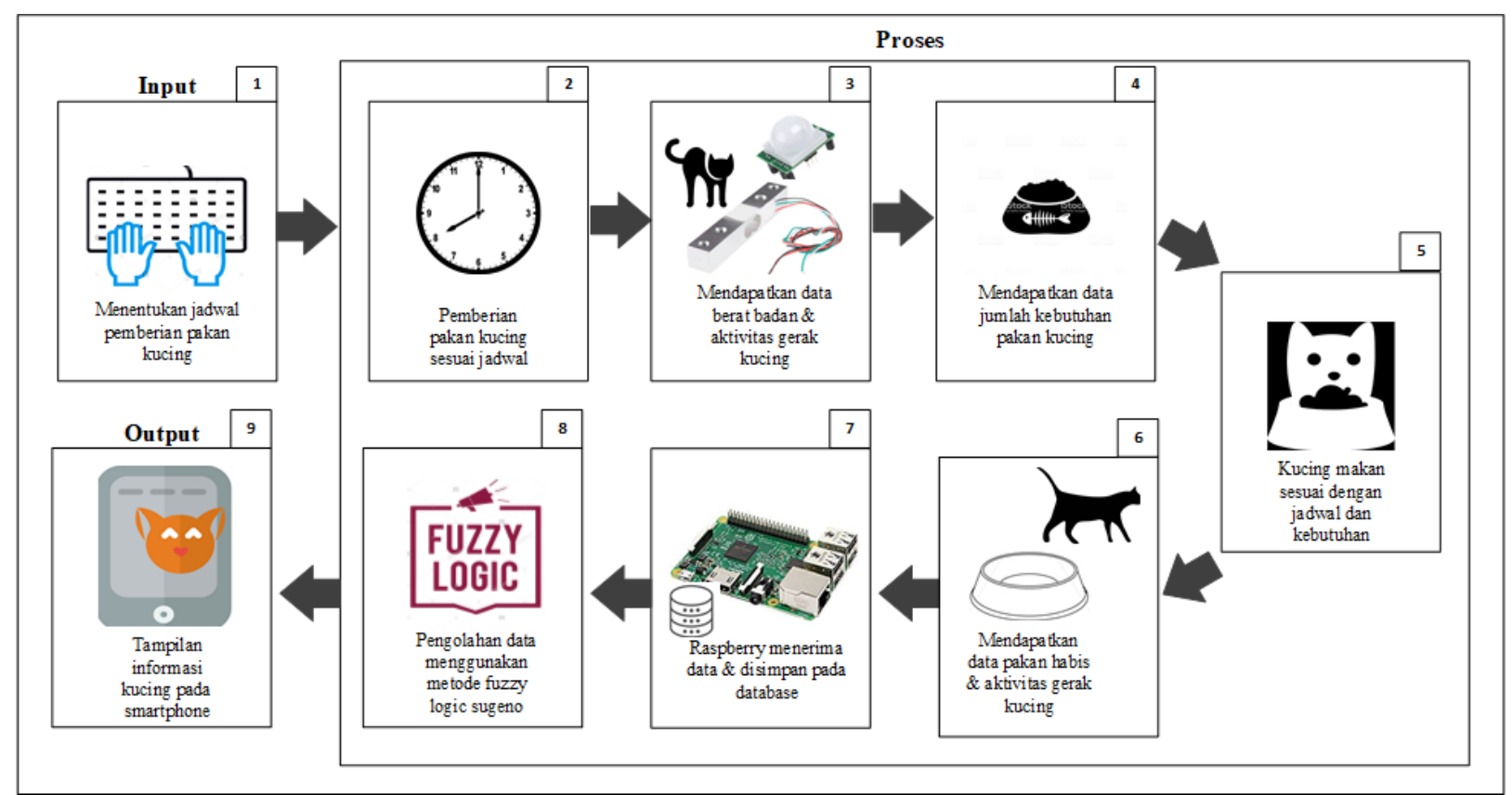

Gambar 5. Workflow Sistem

1. Pengguna menentukan jadwal pemberian pakan kucing.

2. Pemberian pakan kucing akan dilakukan sesuai jadwal yang telah ditentukan sebelumnya.

3. Sensor berat akan mendeteksi berat badan kucing dan sensor gerak akan mendeteksi aktivitas gerak kucing.

4. Setelah mendapatkan data berat badan kucing, sistem akan menentukan jumlah pemberian pakan kucing.

5. Pemberian pakan kucing akan dilakukan oleh sistem sesuai dengan jadwal dan kebutuhan pakan kucing.

6. Setelah kucing selesai makan maka sensor berat akan mendapatkan data mengenai jumlah pakan yang dihabiskan kucing dan mendapatkan data mengenai aktivitas gerak kucing.

7. Raspberry Pi menerima, menyimpan dan mengolah data mengenai jumlah pakan yang dihabiskan kucing dan aktivitas gerak kucing.

8. Data yang diperoleh kemudian diolah dengan menggunakan metode fuzzy logic Sugeno sehingga mendapatkan hasil mengenai kondisi kesehatan kucing.

9. Smartphone akan menampilkan informasi kepada pengguna mengenai kondisi kesehatan kucing.

\subsection{Flowchart}

Pada Gambar 6. merupakan alur kerja secara umum, penjelasan dari setiap prosesnya sebagai berikut. 


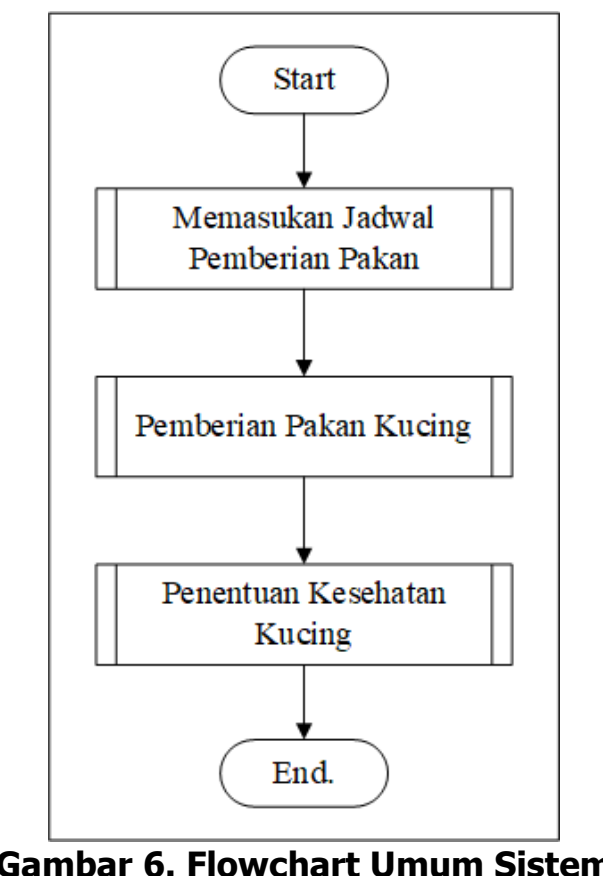

1. Memasukkan jadwal pemberian pakan kucing. Proses ini dilakukan untuk menentukan jadwal pemberian pakan kucing sehingga kucing memiliki jadwal pakan yang teratur.

2. Pemberian Pakan Kucing. Proses ini dilakukan sesuai jadwal dan jumlah pemberian pakan diatur berdasarkan kebutuhan pakan kucing.

3. Penentuan Kesehatan Kucing. Proses ini dilakukan untuk menentukan kondisi kesehatan kucing dengan menggunakan metode fuzzy logic Sugeno berdasarkan pakan yang dihabiskan kucing dan aktivitas gerak kucing.

\section{HASIL DAN PEMBAHASAN}

\subsection{Hasil Pengujian}

Pada bagian ini dilakukan pengujian dari sistem yang telah dibuat. Pada Tabel 5. merupakan identitas dari kucing peliharaan yang digunakan pada penelitian.

\section{Tabel 5. Identitas Kucing}

\begin{tabular}{|l|l|l|l|}
\hline & Kucing 1 & Kucing 2 & Kucing 3 \\
\hline Ras & Domestik & Domestik & Domestik \\
\hline Jenis Kelamin & Betina & Betina & Betina \\
\hline Berat Badan & $3 \mathrm{~kg}$ & $3 \mathrm{~kg}$ & $3 \mathrm{~kg}$ \\
\hline Umur & 1 Tahun & 2 Tahun & 4 Tahun \\
\hline
\end{tabular}

Pada Gambar 7. merupakan grafik mengenai data pakan kucing yang dilakukan selama 21 hari. Pada penelitian ini, pakan kucing yang diberikan sebanyak 55 gram karena menurut drh. Prananda Eka $\mathrm{R}$, masing-masing kucing termasuk ke dalam kategori berat $3 \mathrm{~kg}$ sehingga pakan normal yang diberikan berkisar antara 40-60 gram. 


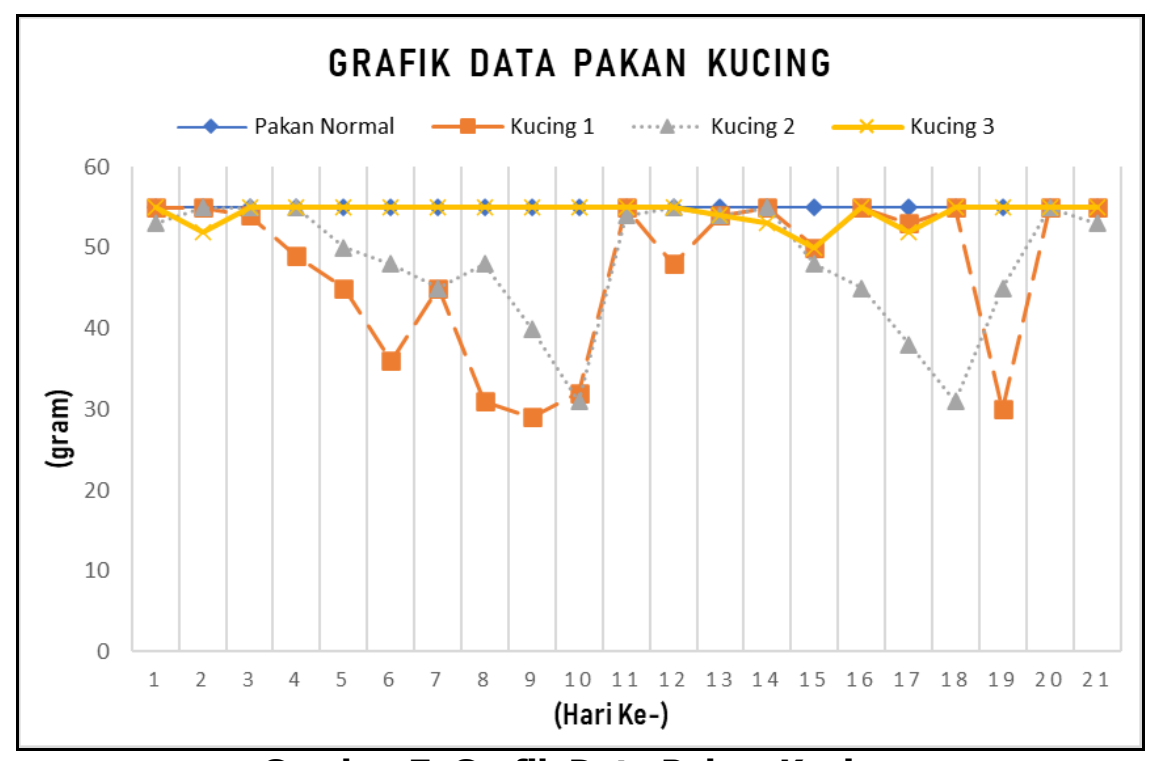

Gambar 7. Grafik Data Pakan Kucing

Pada Gambar 8. merupakan grafik mengenai daerah tempat masing-masing kucing bergerak per harinya. Menurut drh. Prananda Eka R, aktivitas gerak kucing dapat dilihat dari ke mana saja si kucing bergerak apabila diletakan pada ruangan. Pada grafik tersebut terdapat 4 daerah tempat bergerak diantaranya daerah di sekitar tempat makan, minum, litter box dan bermain karena pada penelitian ini kucing diletakan pada ruangan.

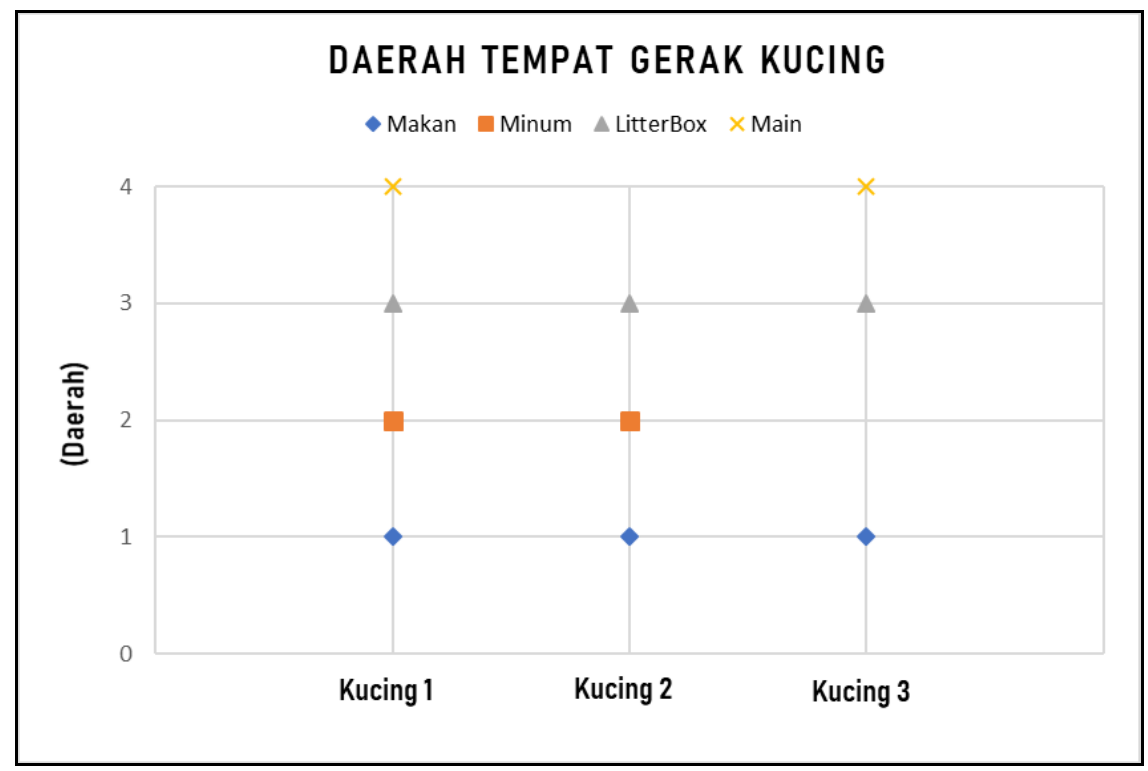

Gambar 8. Grafik Daerah Tempat Gerak Kucing

Pada Gambar 9. merupakan grafik mengenai data gerak kucing yang dilakukan selama 21 hari. Data gerak kucing didapatkan dari jumlah gerakan kucing yang terdeteksi oleh sensor gerak (PIR) yang diletakan di tempat tertentu seperti yang dijelaskan sebelumnya pada Gambar 8. 


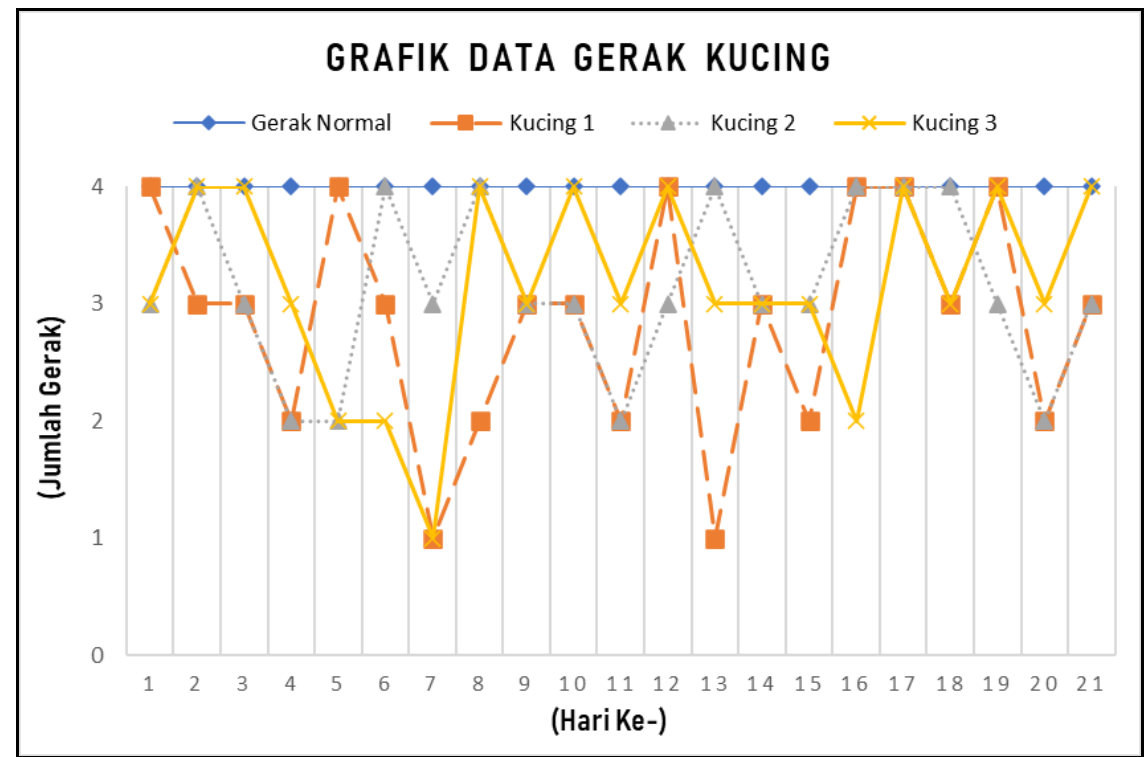

Gambar 9. Grafik Data Gerak Kucing

\subsubsection{Pengujian Perhitungan Fuzzy Logic Sugeno}

Pada pengujian ke-1, didapatkan data mengenai kategori kucing 3kg, pakan habis $=55$ gram dan aktivitas gerak $=4$, maka tahapannya sebagai berikut:

1. Fuzzyfikasi

Pada Gambar 10. merupakan grafik derajat keanggotaan gerak kucing.

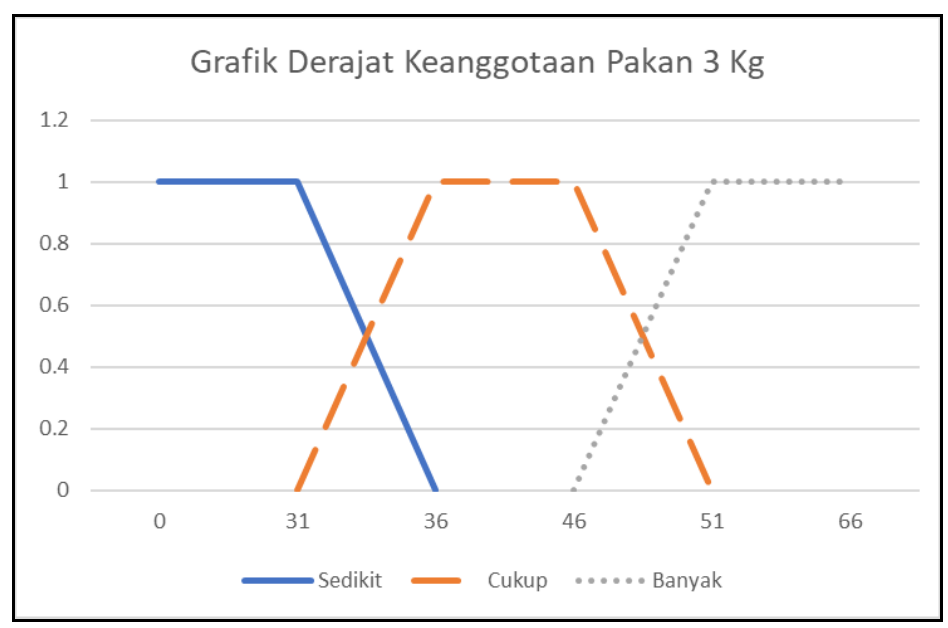

Gambar 10. Grafik Derajat Keanggotaan Pakan Kategori 3kg

Perhitungan nilai fuzzyfikasi untuk variabel pakan habis menggunakan fungsi trapesium seperti yang ditunjukkan sebelumnya pada Persamaan 1.

- Trapesium Sedikit

$$
\mu \operatorname{Sedikit}(x)=\left\{\begin{array}{cr}
1 ; \quad x \leq 31 \\
\frac{36-x}{36-31 ;} ; 1<x<36 \\
0 ; \quad x \geq 36
\end{array}\right.
$$


- Trapesium Cukup

- Trapesium Banyak

$$
\mu \operatorname{Cukup}(x)=\left\{\begin{array}{cc}
0 ; x \leq 31 \text { atau } x \geq 51 \\
\frac{x-31}{36-31} ; 31<x<36 \\
\frac{51-x}{51-46} ; 36 \leq x \leq 46
\end{array}\right.
$$

$$
\mu \operatorname{Banyak}(x)=\left\{\begin{array}{cr}
0 ; & x \leq 46 \\
\frac{x-46}{51-46} ; 46 & <x<51 \\
1 ; & x \geq 51
\end{array}\right.
$$

Berikut merupakan perhitungan fuzzyfikasi untuk variabel pakan habis dengan nilai 55 gram dengan kategori berat badan $3 \mathrm{~kg}$ :

$\mu$ Sedikit [55] $=0 ; 55 \leq 36$

$\mu$ Cukup $[55]=0 ; 36<55<46$

$\mu$ Banyak $[55]=1 ; 55 \geq 46$

Pada Gambar 11. merupakan grafik derajat keanggotaan gerak kucing.

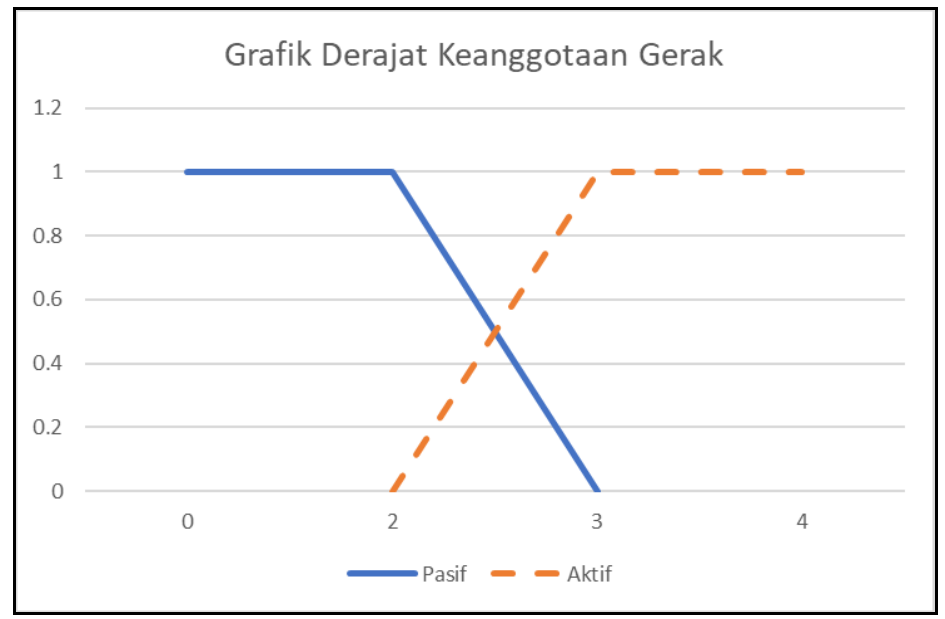

Gambar 11. Grafik Derajat Keanggotaan Gerak

Perhitungan nilai fuzzyfikasi untuk variabel aktivitas gerak kucing menggunakan fungsi trapesium seperti yang ditunjukkan sebelumnya pada Persamaan 1.

- Trapesium Pasif

$$
\mu \operatorname{Pasif}(x)=\left\{\begin{array}{cr}
1 ; & x \leq 2 \\
\frac{3-x}{3-2} ; & 2<x 3 \\
0 ; & x \geq 3
\end{array}\right.
$$

- Trapesium Aktif

$$
\mu \operatorname{Aktif}(x)=\left\{\begin{array}{cr}
0 ; & x \leq 2 \\
\frac{x-2}{3-2} ; & 2<x<3 \\
1 ; & x \geq 3
\end{array}\right.
$$

Berikut merupakan perhitungan fuzzyfikasi untuk variabel gerak dengan nilai 4:

$\mu$ Pasif $\quad[4]=0 ; 4 \leq 2$

$\mu$ Aktif $[4]=1 ; 4 \geq 3$ 
Metode Fuzzy Logic Pada Sistem Pemantauan dan Pemberian Pakan Kucing Berbasis Smartphone

2. Mesin Inferensi Fuzzy

Pada tahapan ini setiap variabel akan dibandingkan sesuai dengan aturan yang telah dibuat. Untuk fuzzy logic Sugeno menggunakan fungsi minimum. Pada Tabel 6. merupakan hasil implikasi setiap rule pada kasus ini.

Tabel 6. Hasil Implikasi Rules Kucing Ke-1

\begin{tabular}{|c|l|}
\hline Rule ke- & Hasil Implikasi \\
\hline 1 & $\operatorname{Min}(0,1)=0$ \\
\hline 2 & $\operatorname{Min}(1,1)=0$ \\
\hline 3 & $\operatorname{Min}(1,0)=0$ \\
\hline 4 & $\operatorname{Min}(1,1)=0$ \\
\hline 5 & $\operatorname{Min}(2,0)=0$ \\
\hline $\mathbf{6}$ & $\operatorname{Min}(\mathbf{2}, \mathbf{1})=\mathbf{1}$ \\
\hline
\end{tabular}

3. Defuzzyfikasi

Selanjutnya menghitung defuzzyfikasi dengan rumus rata-rata (average) seperti yang ditunjukkan pada Persamaan 2. Pada Tabel 7. merupakan nilai dari status yang akan digunakan pada proses perhitungan defuzzyfikasi.

Tabel 7. Nilai Status

\begin{tabular}{|l|l|}
\hline Status & Nilai \\
\hline Normal & 1 \\
\hline Cukup Normal & 0.5 \\
\hline Tidak Normal & 0 \\
\hline
\end{tabular}

Rule 6 : If (Makan Banyak) and (Gerak Aktif) Then Normal

$$
\begin{aligned}
\text { Defuzzyfikasi }= & ((\text { rule } 1 \times \text { tidaknormal })+(\text { rule } 2 \times \text { cukupnormal })+(\text { rule } 3 \times \text { normal }) \\
& +(\text { rule } 4 \times \text { normal })+(\text { rule } 5 \times \text { cukupnormal })+(\text { rule } 6 \times \text { normal })) /(\text { rule } 1 \\
& + \text { rule } 2+\text { rule } 3+\text { rule } 4+\text { rule } 5+\text { rule } 6) \\
& =\frac{(0 \times 0)+(0 \times 0,5)+(0 \times 1)+(0 \times 1)+(0 \times 0,5)+(1 \times 1)}{n+n+0+n+0+1}=1
\end{aligned}
$$

Pada Gambar 12. merupakan grafik mengenai status kucing yang dilakukan sebanyak 21 hari. Data status kucing didapatkan dari hasil perhitungan metode fuzzy logic Sugeno berdasarkan pakan yang dihabiskan kucing dan aktivitas gerak kucing.

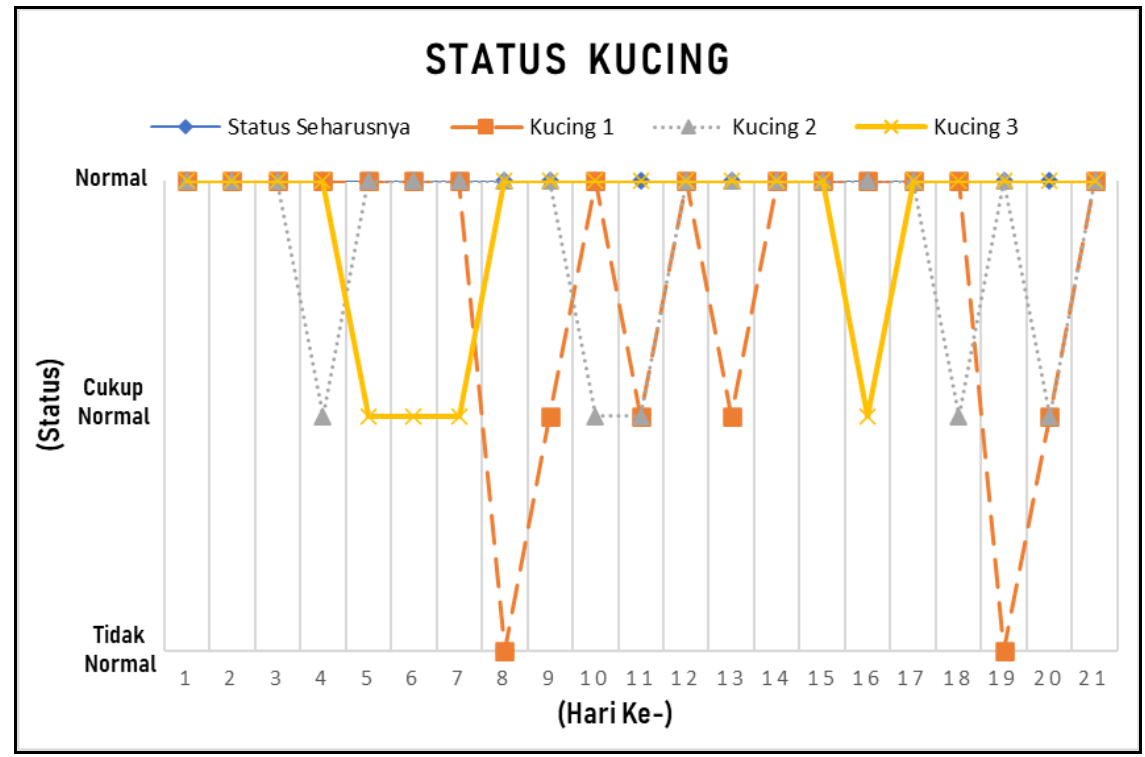

Gambar 12. Status Kucing 
Pada Tabel 8. merupakan tabel mengenai status kucing yang sebelumnya direpresentasikan pada Gambar 12.

Tabel 8. Pengujian Status Kucing

\begin{tabular}{|c|c|c|c|}
\hline $\begin{array}{c}\text { Pengujian } \\
\text { Ke- }\end{array}$ & Kucing 1 & Kucing 2 & Kucing 3 \\
\hline 1 & Normal & Normal & Normal \\
\hline 2 & Normal & Normal & Normal \\
\hline 3 & Normal & Normal & Normal \\
\hline 4 & Normal & Cukup Normal & Normal \\
\hline 5 & Normal & Normal & Cukup Normal \\
\hline 6 & Normal & Normal & Cukup Normal \\
\hline 7 & Normal & Normal & Cukup Normal \\
\hline 8 & Tidak Normal & Normal & Normal \\
\hline 9 & Cukup Normal & Normal & Normal \\
\hline 10 & Normal & Cukup Normal & Normal \\
\hline 11 & Cukup Normal & Cukup Normal & Normal \\
\hline 12 & Normal & Normal & Normal \\
\hline 13 & Cukup Normal & Normal & Normal \\
\hline 14 & Normal & Normal & Normal \\
\hline 15 & Normal & Normal & Normal \\
\hline 16 & Normal & Normal & Cukup Normal \\
\hline 17 & Normal & Normal & Normal \\
\hline 18 & Normal & Cukup Normal & Normal \\
\hline 19 & Tidak Normal & Normal & Normal \\
\hline 20 & Cukup Normal & Cukup Normal & Normal \\
\hline 21 & Normal & Normal & Normal \\
\hline
\end{tabular}

Untuk kucing ke-1, dari 21 data pengujian terdapat 15 status kucing yang sesuai dengan status seharusnya yaitu normal dan 6 data tidak sesuai dengan status normal. Dari data tersebut didapatkan hasil mengenai kondisi kesehatan kucing sebesar $71 \%$. Persentase Kondisi kesehatan kucing diperoleh dengan mengambil data dari jumlah status normal pada kucing lalu diterapkan menggunakan Persamaan 3 (Wachdani et al., 2012).

$$
\begin{aligned}
\text { Persentase Kesehatan } & =\frac{\sum \text { Status Normal }}{\sum \text { Status Total }} \times 100 \% \\
& =\frac{15}{21} \times 100 \%=71 \%
\end{aligned}
$$

Sedangkan kucing ke-2, dari 21 data pengujian terdapat 16 data status kucing yang sesuai dengan status seharusnya yaitu normal dan 5 data tidak sesuai dengan status normal, dari data tersebut didapatkan hasil mengenai kondisi kesehatan kucing sebesar $76 \%$. Untuk kucing ke-3, dari 21 data pengujian terdapat 17 data status kucing yang sesuai dengan status seharusnya yaitu normal dan 4 data tidak sesuai dengan status normal, dari data tersebut didapatkan hasil mengenai kondisi kesehatan kucing sebesar $80 \%$.

Dilihat dari hasil penelitian yang sudah dilakukan maka dapat disimpulkan bahwa nilai yang diperoleh untuk kondisi kucing 1 sebesar 71\%, kucing 2 sebesar 76\% dan kucing 3 sebesar $80 \%$ termasuk ke kondisi kucing sehat dengan range nilai diantara 50\%-100\%. Kondisi ini mengacu pada Tabel 9. sehingga tindakan yang perlu dilakukan pemilik kucing yaitu tetap menjaga pola pakan kucing. 
Tabel 9. Kondisi Kesehatan Kucing

\begin{tabular}{|l|l|l|}
\hline Kondisi & Nilai (\%) & Tindakan \\
\hline Sakit & $0-30$ & $\begin{array}{l}\text { Segera bawa kucing ke dokter } \\
\text { hewan }\end{array}$ \\
\hline Kurang Sehat & $30-50$ & Pemberian suplemen / vitamin \\
\hline Sehat & $50-100$ & Menjaga pola pakan kucing \\
\hline
\end{tabular}

\subsubsection{Pengujian Menampilkan Informasi Pada Smartphone}

Pengujian pada smartphone dilakukan untuk menampilkan informasi mengenai data pakan kucing, data status dan kondisi kesehatan kucing yang didapatkan dari hasil perhitungan metode fuzzy logic Sugeno. Pengujian ini direpresentasikan pada Gambar 13.

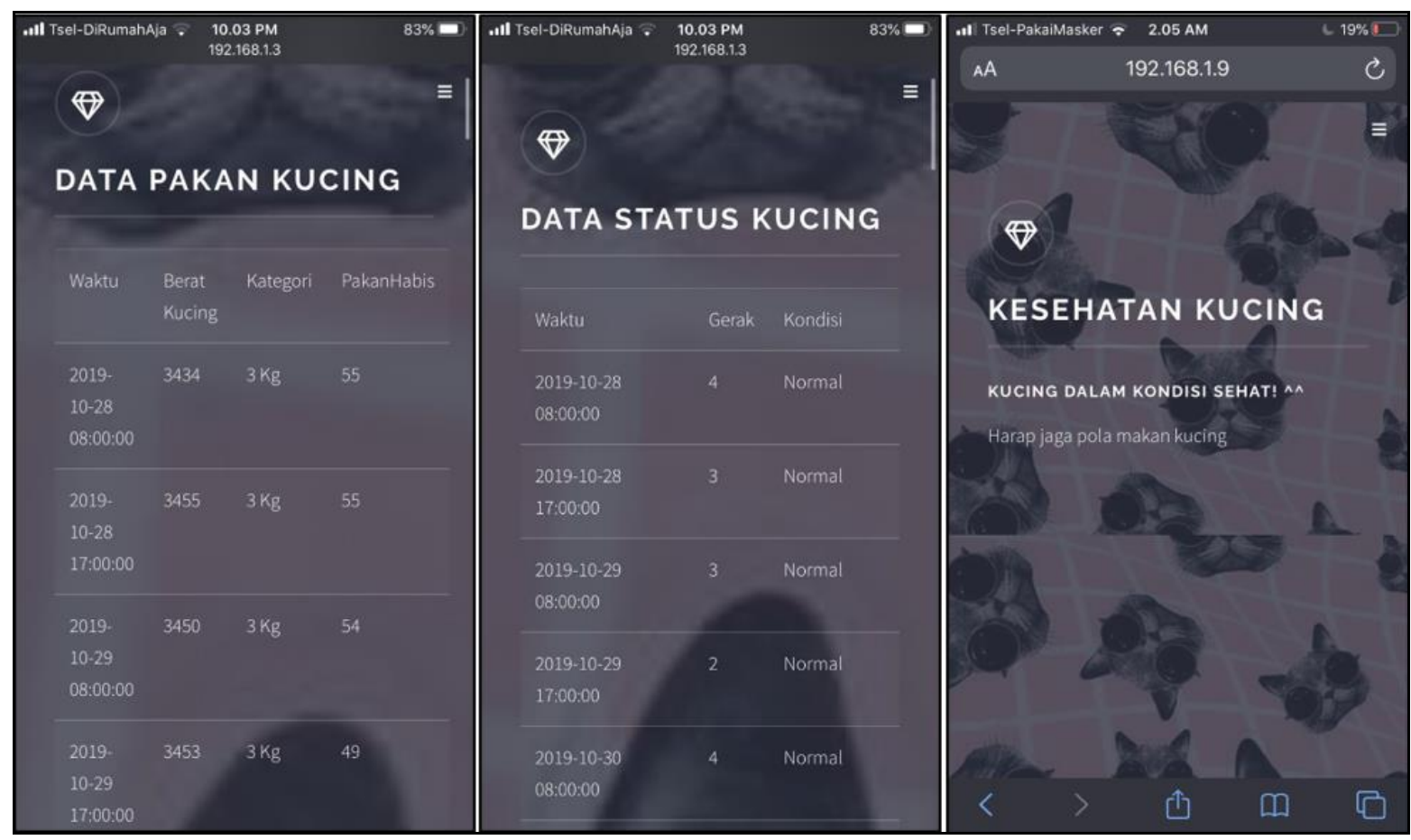

Gambar 13. Pengujian Menampilkan Data Pada Smartphone

Pada penelitian yang telah dilakukan memanfaatkan perangkat keras (Hardware) seperti Raspberry pi, sensor berat (Load Cell), sensor gerak (PIR) dan motor servo sehingga dapat menghasilkan sebuah sistem pemberian pakan kucing dan sistem berhasil memberikan pakan kucing sesuai jadwal yang telah ditentukan sebelumnya oleh pengguna yaitu pada pukul 08:00 dan pukul 17:00 serta kebutuhan jumlah pakan yang diberikan sebanyak 55 gram sesuai dengan berat badan kucing dan sistem berhasil memberikan informasi mengenai kondisi kesehatan kucing dengan menggunakan metode fuzzy logic Sugeno serta sistem berhasil menampilkan informasi pada smartphone berupa data pakan kucing, data status kucing dan kondisi kesehatan kucing.

\section{KESIMPULAN}

Sistem pemberian pakan kucing memanfaatkan kecerdasan buatan sehingga pemberian pakan kucing dapat dilakukan secara terjadwal dan kucing mempunyai pola jam pakan yang teratur. Smartphone dimanfaatkan oleh pengguna untuk dapat memasukkan jadwal pemberian pakan kucing, memberikan pakan kucing secara manual (tidak sesuai jadwal pemberian pakan), mengetahui informasi mengenai data pakan kucing, data aktivitas gerak kucing dan kondisi kesehatan kucing. Untuk dapat mengetahui kondisi kesehatan kucing, 
digunakan metode fuzzy logic Sugeno berdasarkan pakan yang dihabiskan kucing dan aktivitas gerak kucing. Hasil yang didapat dari pengujian metode fuzzy logic Sugeno yaitu kucing ke-1 mendapatkan nilai status sebesar $71 \%$, kucing ke-2 mendapatkan nilai status sebesar $76 \%$ dan kucing ke-3 mendapatkan nilai status sebesar $80 \%$. Nilai status tersebut digunakan untuk menentukan kondisi kesehatan kucing, sehingga semua kucing termasuk ke dalam kategori kondisi kucing sehat dan tindakan yang perlu dilakukan oleh pemilik kucing yaitu dengan menjaga pola makan kucing.

\section{DAFTAR RUJUKAN}

Baehaki, M. H., \& Lestariningati, S. I. (2017). Alat Pemberi Pakan Hewan Peliharaan Menggunakan Perangkat Mobile. 1-8.

Elliott, P. (2021). How to Know if Your Cat Is Sick. https://www.wikihow.com/Know-if-YourCat-Is-Sick

Hartuti, R. S., Adam, M., \& Murtina, T. (2013). Kajian Kesejahteraan Kucing yang Dipelihara Pada Beberapa Pet Shop Di Wilayah Bekasi, Jawa Barat. Medika Veterinaria, 8(1), 3742.

Komaeni, N. (2016). Perancangan Sistem Monitoring Dan Pemberian Makan Kucing Menggunakan Web Browser Berbasis Raspberry Pi Pada Bless Pet House. https://widuri.raharja.info/index.php?title=SI1133465638

Lestari, F. A. (2016). Implementasi Algoritma Fuzzy Sugeno untuk Pengaturan Clue pada Game Ali and The Labirin.

Mahargiyak, E., Anggraeni P, D., Wandiro S, R., \& Mahzar, Y. (2013). Penerapan Logika Fuzzy Metode Sugeno untuk Sistem Pendukung Keputusan Prakiraan Cuaca. 100.

Princy, S., \& Dhenakaran, S. S. (2016). Comparison of Triangular and Trapezoidal Fuzzy Membership Function. Journal of Computer Science and Engineering, 2(8), 46-51.

Trimartanti, L. W. (2011). Penerapan Sistem Fuzzy Untuk Diagnosis Campuran Bahan Bakar Dan Udara Pada Mobil F15 Gurt. Fakultas Matematika Dan Ilmu Pengetahuan Alam Universitas Negeri Yogyakarta, 7-37. http://eprints.uny.ac.id/43552/

Vadreas, A. K., \& Nirad, D. W. S. (2018). E Consulting Dalam Penanganan Kesehatan Kucing Ras (Klinik Kucing) Dengan Metode Forward Chaining. PROSIDING SEMINAR NASIONAL SISFOTEK.

Wachdani, R., Abidin, Z., \& Yaqin, M. A. (2012). Aplikasi Fuzzy Inference System (Fis) Metode Sugeno Dalam Menentukan Kebutuhan Energi Dan Protein Pada Balita. Matics. https://doi.org/10.18860/mat.v0i0.1565 